\title{
THE CLASSIFICATION AND FRAMING OF RELIGIOUS DIALOGUE IN TWO ENGLISH
}

\section{SCHOOLS}

\section{NIGEL FANCOURT, UNIVERSITY OF OXFORD}

ABSTRACT

This article explores the place of discourse about religions in education by comparing two very different schools. It initially outlines some of the current debates around religious discourse, notably in dialogue. A theoretical frame for analysing religious discourse in schools is proposed, combining a theorisation of three levels of dialogue with both notions of classification and framing, and a distinction between the formal curriculum and the institutional curriculum. Research in 'Flintmead' and 'Headley' is then described: the former an elite Anglican private boarding school, the latter a secular non-selective state day school. The analysis shows how the schools build complex structures across the different dialogical levels, between and within the formal and institutional curriculum, with varying strengths of classification and framing. In particular, similar approaches to religious education sit alongside different discursive structures. The implications of the study for further comparison are discussed, and for understandings of religious dialogue. 


\section{INTRODUCTION}

The place of religions in education is contested internationally, being both encouraged and critiqued (Cooling 2010; Chélini-Pont 2011; Russo 2012; Zucca 2013; Davies 2014). In many countries, the number and type of 'faith' schools has increased; in England, more state-maintained schools with a religious ethos have been established under both New Labour (Walford 2008) and the current Coalition government (Wright 2012), often as academies and free schools. Their expansion is based on a long-standing argument that they transform pupils' attainment and moral education (e.g. Bryk et al. 1993; Morris 1998; Pike 2010), though they are also criticised for being socially selective, implicitly favouring middle-class children (Allen and West 2011). By contrast, how schools address pupils' religiosity has attracted attention, for instance, whether faith schools inculcate religious intolerance (Gardner et al. 2005), or the effect of anti-radicalisation policies (Gearon 2013). Woven within these is an ongoing discussion about the role and nature of religious education within increasingly pluralistic and secularised societies (Franken and Loobuyk 2011; Conroy et al. 2014; Fancourt 2014).

These overlapping debates have often focused on the value of 'dialogue', which is usually understood positively, but used in different ways. The most obvious is for dialogue between pupils of different religions within a school, seen as being an almost self-evident requirement of life in a multi-faith society (Zucca 2013); thus pupils from diverse religious backgrounds should be encouraged to talk to each other. This can extend to dialogue between pupils in different schools, often using technology (McKenna et al. 2007; Ipgrave 2009). It also describes encountering different religious ideas within the curriculum (Fancourt 2007, 2009), not only through interaction with peers; this often overlaps with demands for dialogical pedagogies across the curriculum, particularly in 
Vygotskian approaches to teaching and learning which highlight the instrumental value of classroom talk (e.g. Alexander 2000; Mercer and Littlejohn 2007; Fancourt 2015). These different elements are found within the 'REDCo' project (Religion in Education: a contribution to Dialogue or a factor of Conflict in transforming societies of European Countries?), which considered pupils' attitudes towards different religions in eight countries, and their experiences of learning about religions, whether in religiously segregated or mixed schools and classes (Valk 2009), and the nature of classroom dialogue (ter Avest et al. 2009). A different interpretation describes how religious education is in dialogue with other disciplines, e.g. theology or sociology (Cush and Robinson 2014; Rothgangel 2014), though this is not pursued here.

What emerges is that dialogue is mediated by wider institutional patterns, from the structure of the curriculum to the recruitment of staff on religious grounds, or to the provision of space for religious devotion. There is a need for effective theoretical tools for exploring religion in schools (Green 2012), and some recent research has used Bakhtin's $(1981,1984)$ theory of dialogical discourse, notably Ipgrave (2009, 2012, 2013; McKenna et al. 2008). This differs from its use in dialogical pedagogies (Matusov 2009; White and Peters 2011), and in theories of cultural agency (Holland et al. 1998). Bakhtin, primarily a literary critic, analysed how writers orchestrate different types of language to create a richly textured discourse, especially by juxtaposing their own authoritative voice against other voices. Discourse is divided and stratified into different forms, as 'dialects', literally and metaphorically, to include "languages of social groups, "professional" and "generic" languages, languages of generations' (Bakhtin 1981, p. 272) so that there is a permanent creative tension between a text's unitary language and its internal 'heteroglossia' (p. 263): thus dialogue is an ontological state (Matusov 2009). Here the school institutionally is analogous to the author, so a Bakhtinian analysis seeks to disentangle these different 'dialects' within its unitary voice. Ipgrave and colleagues developed a threefold stratification of discourse about religions in schools: primary 
dialogue 'provides a context for other forms of dialogue' (McKenna et al. 2008, p. 18), in how schools recognise diversity and difference, particularly in their identity; secondary dialogue represents the ways that recognition of these differences is institutionalised, particularly in the curriculum; tertiary dialogue 'is the activity of dialogue itself - the forms and structures of verbal interchange' (ibid.), notably in classrooms. Dialogical pedagogies are located within tertiary dialogue, but this approach includes other structural aspects of religious discourse in schools. Ipgrave subsequently elaborated a typology of three different approaches to religion in schools: 'doxological, sacramental, instrumental, founded, respectively, on certain faith in God, on openness to the possibility of God, and on a default scepticism' (Ipgrave 2012, p. 30). In further work on institutional responses to different voices, she has analysed how various schools respond to diversity (Ipgrave 2010, 2014; Ipgrave et al. 2011).

Bakhtin's ideas provide a starting point, however they have been criticised for not taking into account issues of power in educational discourse (Hasan 2012). For this, Bernstein's (1973) sociolinguistic theories of classification and framing of the curriculum have proved insightful: both generally, notably when combined with socio-cultural models (Daniels 2012; Hasan 2012); and also when considering religions and religious education in schools (Grace 2002; Walford 2006; Stern 2010). Bernstein focused on the control of language, suggesting that curriculum and pedagogy could be categorised according to codes. First, the classification of contents, thus 'where classification is strong, contents are well insulated from each other by strong boundaries' (Bernstein 1973, p. 231), typically with separate subjects, not a fluid, 'creative' curriculum, which would be weak classification. Second, framing describes the 'form of the context in which knowledge is transmitted and received' (p. 231); this means the extent to which an individual controls their discourse, e.g. if a teacher chooses the curriculum (weak framing), or the school or government (strong framing), or if pupils have to learn what is presented to them (strong), or choose what is taught and said (weak): 
strong classification and framing leads to a 'restricted code', whereas if both are weak an 'elaborated code' emerges.

Other researchers have refined Bernstein's approach to differentiate between the taught curriculum and other aspects of school life. For example, Walford (2006) adapted Bernstein's approach when researching boarding schools (not solely in relation to religion) by suggesting that there is both a formal curriculum and a 'formal extra-curriculum'. The formal curriculum is usually strongly classified and framed; traditional subject disciplines are maintained, in response to external examination regulations to perform, and therefore pupils and even their teachers have little control over the content of learning. Alongside this, they provide sporting and cultural activities, as a formal extra-curriculum, which is weakly classified and framed. Boarding schools' distinctiveness is the interplay between these two elements: 'pupils experience a total curriculum in which work and play are intertwined' (Walford 2006, p. 71). The religious dimension in boarding schools might be through chapel, or support for pupils' religious background. Whilst day schools obviously do not provide this formal extra-curriculum, they do structure a wide range of institutional conditions for recognising and dealing with religions, through assemblies, in support for religious observance or dietary obligations, or in dealings with local religious institutions: the term 'institutional curriculum' is used for this, however it should not be confused with an 'informal curriculum', i.e. the latent messages pupils receive within education (Eshel and Koriat 2001).

Bernstein and Bakhtin both recognised the particular properties of religious discourse (Bernstein 1973, p. 19; Felch and Contino 2001). A Bakhtinian model contextualises how schools both react to wider religious differences, and as a site within which these differences interact; however, it does 
not do justice to the patterns of school decision-making in dealing with these differences. A Bernsteinian model provides a strong account of how schools structure the ways which pupils can learn and develop, i.e. how power is exercised, but it does not address how wider religious and cultural arguments flow across schooling. The combination enables analysis of the differences between the levels of dialogue, considering each in terms of classification and framing. Further, for the secondary and tertiary levels, a distinction can be made between the formal curriculum and the institutional curriculum. In particular, the extent to which the school separates out different religions and beliefs is a form of classification: how the school demarcates boundaries between them, for instance in teaching religious education systematically (treating each religion separately), i.e. strongly, or thematically (one theme across several religions), i.e. weakly. The inter-relationship between these approaches is shown diagrammatically, in Fig 1.

\section{INSERT TABLE 1 HERE}

Separating levels of dialogue allows differences between the responses of school, the teachers and the pupils to be unravelled, to show how institutional discourse can be complexly structured, in and between differently textured speech genres. The focus is not simply on whether pupils enter into dialogue in their lessons, as a form of weak framing, but on the structural properties of discourse across the school.

\section{METHODOLOGY}

This article is based on research for the English government on materials used in religious education 
(Jackson et al. 2010), which was a mixed-methods study including a synthesis of twenty case studies of schools (p. 121-175). These were purposively selected, and six researchers conducted individual studies, which were then synthesized (see Ipgrave 2012). Here, data from two schools have been reanalysed in the light of an emergent theoretical model, allowing for a nuanced picture of the similarities and differences to emerge. This differs from case studies that treat a school's entire approach as a unified whole, valuable though this is, whether individual studies (Breen 2009; Pike 2010) or comparisons (Ipgrave 2014); it is similar to other analyses which contrast different voices within one institution (Miller and McKenna 2011; Green 2012, 2014).

Apart from the fact that both are secondary schools, the two could hardly be more different. Flintmead School is an independent elite selective boys' boarding school, with mostly White pupils from a nominally Christian background, and situated on the edge of a small largely mono-cultural city. Headley School is a non-selective mixed state day school with a wide range of religions and ethnicities within a socio-economically mixed quarter of a moderately large city. The research was conducted in 2010, comprising: participant observation around the schools; lesson observations; interviews with various staff; student group interviews, from a range of years, and with students from a range of religious traditions. School documents were analysed, notably the prospectus, website, statistical data, newsletters, and religious education documents and resources. The short time in the field inevitably meant that informal pupil discourses were not explored in depth. University of Warwick ethical codes applied; the school and interviewees have been anonymised and disguised, and some documentation has been paraphrased.

PRIMARY DIALOGUE 
At the level of primary religious dialogue, the schools' positions contrasted greatly; within Ipgrave's (2012) typology, Flintmead had a 'sacramental' approach, whereas Headley's was 'instrumental'. In terms however of their coding, they were very similar. Flintmead was strongly classified but weakly framed: although it had a clear Anglican identity, demarcating itself clearly religiously and denominationally, it did not select pupils (or staff) on these grounds, instead choosing pupils on their attainment (and gender). As a comparison of attainment in recent years, in public examinations when aged 16 (GCSEs), all pupils achieved $5 \mathrm{~A}^{*}$ - $\mathrm{C}$ grades (the national benchmark), against the national average of $55 \%$; further, roughly $70 \%$ of these were $A *$ s, the highest grade. Chaplains aside, staff were appointed for their ability teach the curriculum and there was no religious criterion. Pupils came from a variety of religious backgrounds, whether from the UK or abroad, though the majority were at least nominally Christian. Strikingly, Buddhism was the second largest religion (2.5\%), and Islam the least represented. The relatively high proportion of Buddhists was largely explained by the number of Chinese and Chinese heritage pupils, about $10 \%$. These proportions differed from the local population, which was almost completely White, and with almost no religious diversity.

Headley was also strongly classified but weakly framed, in that it demarked itself as a secular school, but with very diverse pupils. While not labelling itself on its website and public documents,

My sense of the philosophical culture of the place...would be that the greatest energy is in a kind of secularism, and a kind of scepticism...There is a secular instinct, or a determinedly agnostic instinct. (Assistant head)

It accepted all pupils within its catchment area, of all levels of attainment and any background: in terms of attainment, against the national average of $55 \%$ GCSEs at $A^{*}$ to $C$, it achieved $57 \%$. Its ethnic diversity replicated the surrounding area, with large Pakistani and Bangladeshi heritage 
communities. About $30 \%$ of the pupils had English as an additional language, with about sixty different home languages spoken. The head set out the pupils' diverse religiosity:

We are a multi-faith school: we have Plymouth Brethren, we have Muslims, we have Hindus, Zoroastrians, Sikhs...We are a predominantly Christian school including Black African Christianity, and European Protestant, Catholicism - and Black Caribbean as well. We have got a very large Muslim population, some of which is from the Middle East, most is from Afghanistan, Pakistan and Bangladesh, and some is from Somalia and Albania...so there are different strains, so for example Ramadan can happen at different times for some groups of our students. (Head)

A deputy head, also a religious education teacher, considered that although the majority were nominally Christian, Islam was more actively practiced.

Both schools therefore positioned themselves as either Anglican or secular, and were fairly strongly classified, but they both were loosely framed in welcoming pupils from diverse religious backgrounds. At the level of primary dialogue, while they said different things, they said them in similar ways.

SECONDARY DIALOGUE: THE INSTITUTIONAL CURRICULUM

The institutional curriculum at Flintmead was strongly classified, in demarcating different religions or denominations separately, and moderately framed in that although its Anglican identity 
underpinned the organisation, other religions and denominations were accorded their own provision. Underpinning the institutional curriculum was a strong conviction that 'the chaplaincy and the chapel [was] the point of the school's moral compass and the school's understanding of itself' (Headmaster). However, this was built upon a strong natural theology, by returning to the school's medieval roots, in the Anselmian notion of 'faith seeking understanding'. This was also educational, since it was 'essential for any intelligent person to be presented with the proposition of God' (Headmaster): faith and reason were not dichotomised.

The school addressed pupils' religious background openly, in that whilst the headmaster would 'much rather that the boys had the experience of real quality Christianity, than a spattering of everything on the surface', he nevertheless thought that the school should provide for pupils' religiosity, as it acted in loco parentis. During the week, pupils were obliged to attend chapel, akin to assembly. However on Sundays, provision was more responsive. Pupils of 'Christian culture' were obliged to attend a chapel or other Christian service, and the term 'culture' was used advisedly in that pupils who were agnostic or atheist would still have to attend chapel. Most pupils attended the Anglican chapel service, but Catholic pupils could attend mass, with a local priest in office. Furthermore, pupils of other religions met in their respective Faith groups, and were not obliged to attend chapel services. Classification was strong in distinguishing different religions, but weakly framed in providing alternatives.

At Headley, classification and framing were more mixed. One the one hand, given that they accepted pupils from different backgrounds, they considered it important to recognise these: 
Because we are a multi-cultural and multi-faith school, we have to take account of students' beliefs. The ethos of the school is that we are together in diversity... so the ethos is one of tolerance and understanding, making sure that they are not ignorant of what other people think (Deputy Head).

This approach extended outside the school day; for example, it provided for the local community by being used as a site for the local Sikh community to meet, and it was also hired by a local Pentecostal church.

On the other hand, there was caution:

While we have the absolute regard for the individual faiths of the individual, we find the collective energies about Religion and Faith things that we want to be watchful and careful of because they can result in anxieties and tensions. (Assistant head)

Issues in the community could spill into school:

We are in an inner-city context, and there are all sorts of problems within the community that are brought into the school (Deputy head)

This wary approach to 'Religion' but concern for pupils' needs showed in two ways. The school adopted the 'Prevent Violent Extremism' programme, though had a 'concern [that] the way that the information is being delivered does not excite the students' (Headley, deputy head). They also acted on child protection issues which pupils raised:

The boys are often telling me that they are being beaten at the mosque and they don't like it. Now I have passed that on to [a local imam], who was going to feed that back. (Deputy Head) 
Also, the school was 'involved in the first [national] conference on forced marriage - that was as a result of things happening here, with female students disappearing, and I had a link with a [local] police officer' (Deputy Head). Thus it supported activities which protected students from what were perceived as harmful aspects of their religious or cultural traditions. However, on the provision of a space for prayer, while the school was prepared to provide space, it considered that the students should organise it:

Students have come during Ramadan...[wanting] a prayer room set up, and I am more than happy to accommodate that, but a $6^{\text {th }}$ former needs to man it...but that is where it always falls down, because I believe that if they have the right intentions then it will happen. (Deputy Head)

Overall, the institutional curriculum in secondary dialogue differed between the two schools. Flintmead followed its primary dialogue, with strong classification and framing. Headley was less strongly classified, more cautious about 'religion', and stronger in its framing, concerned to support its pupils and the wider community, but anxious about issues too.

TERTIARY DIALOGUE: THE INSTITUTIONAL CURRICULUM

At Flintmead, the tertiary level in the institutional curriculum maintained strong classification, but was very diversely framed. Compulsory chapel services with a set liturgical structure provided little opportunity for interaction. Pupils felt that the topics could be thought-provoking, although others were less appreciative: 
I don't think the religion that we do unifies us, except in unified opposition to chapel. (Year 13)

By contrast, pupils in Faith groups were free to organise themselves. Indeed some pupils wanted more structure because it was 'a bit too discussion-based' (Year 10 Buddhist pupil); Jewish pupils wanted 'more interaction with a Rabbi'. The most autonomous were Bible study groups in the boarding houses, which were entirely voluntary and run by the pupils themselves; these included the reading and discussion of a Biblical passage and prayers, and were very loosely classified and framed, their language devotional and personal.

At Headley, the school allowed for some expressions of religiosity; there was voluntary a Christian Union, run by $6^{\text {th }}$ Formers, and the potential for space for prayers during Ramadan, mentioned above. However, there were anxieties about religio-political expressions:

I had some students walking around with badges for the Palestinians, and explained why they should not wear them, and they were fine about that, and I have not seen the badges since. I told them that what I did not want was conflict within the school. (Deputy head)

Thus schools could hardly be more different. In one, religiosity was encouraged and indeed almost expected, and pupils could raise their beliefs quite openly, whereas in the other it was tolerated on institutional terms. But of course, a boarding school is less porous to local voices than a day school for Headley, these voices were direct and immediate, whereas Flintmead could regulate its own internal world.

SECONDARY DIALOGUE: THE FORMAL CURRICULUM 
Despite these different approaches to the institutional curriculum, both schools adopted surprisingly similar approaches to the formal curriculum. The curriculum overall was generally strongly classified, in that different subjects were demarcated clearly, and in religious education they both adopted systematic approaches. Both were loosely framed, in that the while the curriculum was constrained through external examination board criteria, staff were fairly free to decide; Headley had less autonomy, being required to follow the local agreed syllabus, but the head of department considered this 'fairly open'. Strikingly, both departments bore witness to the philosophisation of religious education, and both were anxious about academic performance, having to match other subjects - evidence of neo-liberalism across education.

At Flintmead, the staff consisted of the Head of Department and two other teachers, both the school's ordained chaplains, but they considered the two 'spheres' of religious education and chapel to be distinct. The subject was labelled 'Theology and Philosophy', and the Head of Department, Mr Preston, identified his approach as 'critical realist' (e.g. Wright 2007):

It may be that some of the pupils have faith and some don't...You'll understand why you believe what you believe and examine that as some sort of process of self-examination, and that you understand why it is that other people hold the beliefs that they do.

A chaplain hoped pupils would recognise that being 'prepared to allow your opinion to be shifted by another is not a weakness'. At A level, students studied philosophy of religion and religious ethics, and further down the school, the syllabus consisted of a range of modules arranged systematically; Christianity received more attention, with modules on Mark's Gospel, the New Testament and 
Science and Religion and there were also modules on Judaism, Islam and Buddhism, focusing on beliefs and ethics.

Headley 's approach was almost identical. The head of department highlighted the importance of philosophy of religion, and indicated a strongly classified approach:

Knowledge and understanding of major world faiths, to understand that religion does not mean the same thing to all people in all places at all times.

At A level, the department similarly offered philosophy and ethics. At GCSE, the philosophy and ethics option was provided, focusing on Islam. At Key stage 3, the syllabus generally consisted of systematic modules on different religions. At one level, it is unsurprising that religious education is similar in many schools. What is noteworthy is the effect of this in different institutional settings. Both heads of department pointed to the increasing pressure of examination attainment on them; as a curriculum subject, they were required to produce results, and indeed pupils expected this too:

We have gone that way in order to have status both in the eyes of the pupils and senior management... [Teachers] are congratulated for their efforts and by becoming exam-focused and narrow. (Headley, Teacher)

The same neo-liberal educational demands impinged on both departments, so even though their settings were different, and they had freedom in terms of the detail of the syllabus choice and design, they made similar decisions.

TERTIARY DIALOGUE: THE FORMAL CURRICULUM 
In both schools, lessons were often loosely framed. At Flintmead, the classes observed were often discursive:

We respond better to active styles of learning, [when the teacher] puts comments and gets pupils to comment and react... let the class resolve it in its own way. (Year 12)

They valued hearing different perspectives: 'On the one hand you have a complete atheist and on the other hand a devout Christian...arguing' (Year 12). Moreover, pupils seemed to recognise the difference between the two curriculums in that 'in this setting, religions were treated as evidence or as a theory...not unquestionable truth' (Year 13, emphasis added)

Similarly at Headley, pupils linked religious education to explicit recognition of other pupils' backgrounds:

Obviously understanding everyone's viewpoints, so you are not completely ignorant of them, because we are a multi-cultural school. Obviously RS has a lot to do with what different religions think on ethical topics, because we have such a diverse range of pupils we can learn from other people's religions (Year 11)

The repetition of 'obviously' is striking - the rationale was self-evident to them. Further, they pointed to assessment issues (see Levitt and Muir 2014): 
I think is really good how the lesson is structured, because with everyone sharing their opinion you learn these different viewpoints. Which are really good, so you can use them in your own arguments and exams (Year 11, emphasis added)

Pupils also acknowledged that the subject at Headley adopted a more distanced perspective; one compared it to his previous church school:

My old teacher was really into it...she said that God had told her to do something and, no offence to this teacher, but he is not so into it. (Year 8)

Thus in both Flintmead and Headley, the pedagogical approach was loosely framed, being responsive to pupils' intellectual concerns, but there was strong classification in that they understood religious education as outside or apart from religiosity, and perceived its role to be about learning 'different viewpoints'.

DISCUSSION: SPHERES OF DIALOGUE

Religious discourse in both schools displayed complex patterns across different levels of dialogue, with varying strengths of classification and framing, so that pupils experienced different voices and registers, within a benign but compulsory Anglicanism at Flintmead, and a responsive but wary secularism at Headley. These had different patterns of classification and framing in the institutional curriculum, unsurprising given that one is an elite boarding school, and the other a non-selective day school. Strikingly, in both classification was strong at most levels, in sharp contrast to Walford's (2006) studies of new religious schools which had an overarching weak classification of the formal curriculum, extending religious ideas across it - akin to Ipgrave's (2012) 'doxological' approach. 
Neither school considered that it should inculcate a particular religion or denomination, nor were staff and pupils expected to transmit the school's official position (see Pike 2010, Green 2012). A sacramental approach depended on strong classification at an institutional level, demarcating its own religious position clearly, but with weak framing; similarly an instrumental approach needed articulation, but meant there was little institutional space for pupils' voices outside religion education:
A few years ago, a Sikh pupil came up to me and thanked me, saying "You are the only person who has ever talked about Sikhism in the school. It has only been mentioned once in my whole career, and that was in your lessons" (Head of department)

However, both settings offer different challenges to pupils' personal beliefs. The compulsory nature of institutional religion at Flintmead might be seen as indoctrinatory, but then a supportive ethos might also be beneficial; Headley's impartial secularity might be seen as implicit secular indoctrination, or even-handedness. This was not investigated (see Green 2012; Moulin 2012), though pupils indicated discrepancies. At Flintmead, a Jewish pupil (Year 10) complained of a 'nudge, nudge' form of prejudicial innuendo, and when reviewing a textbook, a Headley pupil exclaimed:

This book is just awful. I am a Christian and I hate my religion from this book. (Year 11, original emphasis)

Further comparative research on pupils' religious identity negotiation in different schools would be insightful.

Both schools actively repositioned themselves in the light of new demands, in a deliberate reevaluation of their discourse with religious voices. At Flintmead, an apparently neo-conservative return to tradition allowed explicit engagement with both the demands of high stakes testing and 
increasingly international religious diversity. In Headley, the school was confronted by voices that percolated into school from outside, in the increasingly diverse local communities, but also subject the same academic pressures. How they conducted dialogue was governed as much by demands on perfomativity as it was by their position on religion, and this had implications on the institutional context for their religious education. In Flintmead, a philosophised religious education could provide a separate 'sphere' from the institution's religious position, whereas in Headley the same approach provided the only formal place for discussion of religions, raising questions about how schools address differently the epistemic status of religions within and outside them.

\section{CONCLUSION}

This article is premised on the value of dialogue in religious education (Fancourt 2007, 2009, 2015), but the purpose of this analysis was to tease apart the inter-relationship between three different aspects of school life which impinge on it: institutional ethos, pupil religiosity, and religious education. The use of a framework based on Bakhtinian dialogue combined with Bernstein's analysis of coding has enabled a nuanced understanding of different levels of dialogue, allowing very different schools to be analytically compared. It particularly shows how a similar approach to religious education can function differently because the subject's dialogicality contrasts with wider organisational dialogues. Further analysis of other schools, both 'secular' and 'faith' might reveal different patterns - a rural state primary school might have a less classified approach to primary dialogue, intermingling secular and religious views fluidly. More generally, schools can be seen as authors of the dialogic space, structuring and entering into different kinds of discourse, and this opens up possibilities for and constraints on multi-layered religious dialogues in schools. Religious 
dialogue is not simply what happens in religious education lesson; it is textured by complex institutional arrangements, and wider discourses beyond the school. 


\section{REFERENCES}

Alexander, R. 2000. Culture and pedagogy: international comparisons in primary education. Oxford: Blackwell.

Allen R. and A. West. 2009. "Religious schools in London: school admissions, religious composition and selectivity." Oxford Review of Education 35(4): 471-494.

http://dx.doi.org/10.1080/03054980903072611

Bakhtin, M. 1981. The dialogic imagination: four essays. Austin: University of Texas Press.

Bakhtin, M. 1984. Speech genres and other later essays. Austin: University of Texas Press.

Bernstein, B. 1973. Class, codes and control. St Albans: Granada.

Breen, D. 2009. "Religious diversity, inter-ethnic relations and the Catholic school: introducing the responsive approach to single faith schooling." British Journal of Religious Education 31(2): 103-115. http://dx.doi.org/10.1080/01416200802661076

Bryk, A., V. Lee and D. Holland 1993. Catholic schools and the common good. Cambridge MA: Harvard University Press. 
Chélini-Pont, B. 2011. "The French model: tensions between laïc and religious allegiances in French State and Catholic schools." In Law, religious freedoms and education in Europe, edited by M. Hunter-Henin, 153-170. Ashgate: Farnham,

Cooling, T. 2010. Doing God in education. London: Theos.

Conroy, J. D. Lundie, R. Davis, V. Baumfield, L.P. Barnes, T. Gallagher, K. Lowden, N. Bourque and K. Wenell. 2013. Does religious education work? A multi-dimensional investigation. London: Bloomsbury.

Cush, D. and C. Robinson. 2014. "Developments in religious studies: towards a dialogue with religious education." British Journal of Religious Education 36( 1): 4-17. DOI: http://dx.doi.org/10.1080/01416200.2013.830960

Daniels, H. (ed.) 2012. Vygotsky and Sociology. Abingdon: Routledge.

Davies, L. 2014. “One size does not fit all: complexity, religion, secularism and education. Asia Pacific Journal of Education." 34(2): 184-199. http://dx.doi.org/10.1080/02188791.2013.875647

Eshel Y. and A. Koriat. 2001. The Informal Curriculum: The Latent Aspect of Psychological Training. School Psychology International, 22: 4, 387-400. http://dx.doi.org/10.1177/0143034301224001 
Fancourt, N. 2007. “The dialogical teacher: pupils' perceptions of good teaching in religious education". In Researching RE teachers, RE Teachers as Researchers, edited by C. Bakker and G. Heimbrock, 53 -67. Münster: Waxmann.

Fancourt, N. 2009. "The "safe forum": difference, dialogue and conflict." In Religious Education research through a Community of Practice, edited by J. Ipgrave, R. Jackson and K. O'Grady, 201-215. Münster: Waxmann.

Fancourt, N. 2014. “Re-defining 'learning about religion' and 'learning from religion': a study of policy change." British Journal of Religious Education, 2014. 1-16.

http://dx.doi.org/10.1080/01416200.2014.923377

Fancourt, N. 2015. "Insiders and Outsiders: task design in learning about religions." In Task Design, Subject Pedagogy and Student Engagement edited by I. Thompson, 170-188. London: Routledge.

Felch, S. and P. Contino (eds.). 2001. Bakhtin and Religion: a feeling for faith. Evanston: Northwestern University Press.

Franken, L. and. P. Loobuyk. 2011. Religious Education in a Plural, Secularized Society: A Paradigm Shift. Münster: Waxmann. 
Gardner, R., Lawton, D. and Cairns, J. 2005. Faith schools: Consensus or conflict, London: RoutledgeFalmer.

Gearon, L. 2013. "The Counter Terrorist Classroom: Religion, Education, and Security." Religious Education: The official journal of the Religious Education Association 108(2): 129-147. http://dx.doi.org/10.1080/00344087.2013.767660

Grace, G. 2002. Catholic schools: missions, markets and morality. London: Routledge.

Green, E. 2012. "Analysing religion and education in Christian academies." British Journal of Sociology of Education" 33(3): 391-407. DOI: http://dx.doi.org/10.1080/01425692.2012.659456

Green, E. 2014. "The negotiation and articulation of identity, position and ethos in joint church academies." Research Papers in Education 29(3): 285-299.

http://dx.doi.org/10.1080/02671522.2014.885727

Hasan. A. 2012. "The concept of semiotic mediation. Perspectives from Bernstein's sociology." In Vygostky and Sociology, edited by H. Daniels, 80-92, Abingdon: Routledge.

Holland, D., W. Lachicotte, D. Skinner and C. Cain. 1998. Identity and Agency in Cultural Worlds. Cambridge, Mass: Harvard University Press. 
Ipgrave, J. 2009. "The language of friendship and identity: children's communication choices in an interfaith exchange." British Journal of Religious Education 31(3): 213-225.

http://dx.doi.org/10.1080/01416200903112292

Ipgrave, J. 2010. "Including the Religious Viewpoints and Experiences of Muslim Students in an Environment that is Both Plural and Secular." Journal of International Migration and Integration, 11(1): 5-22. DOI 10.1007/s12134-009-0128-6

Ipgrave, J. 2012. "Conversations between the Religious and Secular in English Schools." Religious Education: The official journal of the Religious Education Association 107(1): 30-48.

http://dx.doi.org/10.1080/15507394.2013.745361

Ipgrave, J. 2013. "The Language of Interfaith Encounter among Inner City Primary School Children." Religion and education 40(1): 35-49. http://dx.doi.org/10.1080/15507394.2013.745361

Ipgrave, J. 2014. "Identity and inter religious understanding in Jewish schools in England." British Journal of Religious Education. Online article. DOI: 10.1080/01416200.2014.984584

Ipgrave, J., J. Miller and P. Hopkins. 2011. "Responses of Three Muslim Majority Primary Schools in England to the Islamic Faith of Their Pupils." Journal of International Migration and Integration, 11(1): 73-89. DOI 10.1007/s12134-009-0119-7 
Jackson, R., J. Ipgrave, M. Hayward, P. Hopkins, N. Fancourt, M. Robbins and L. Francis. 2010. Materials used to teach about world religions in schools in England. London: DCSF.

Levitt, M and F. Muir 2014." "The Perfect Pupil": Changing Aims and Changing Measures of Success in School RE." British Journal of Religious Education 36(2): 218-233. DOI:

$10.1080 / 01416200.2013 .830957$

Matusov, E. 2009. Journey into dialogic pedagogy. New York: Nova.

McKenna, U., J. Ipgrave and R. Jackson. 2008. Inter Faith Dialogue by Email in Primary Schools: An Evaluation of the Building E-Bridges Project. Munster: Waxmann.

Miller, J. and U. McKenna. 2011. "Religion and religious education: comparing and contrasting pupils' and teachers' views in an English school." British Journal of Religious Education 33(2): 173187. http://dx.doi.org/10.1080/01416200.2011.543599

Mercer, N. and K. Littlejohn. 2007. Dialogue and the development of children's thinking: a sociocultural approach. London: Routledge.

Morris, A. 1998. "So Far, so Good: levels of academic achievement in Catholic schools." Educational Studies 24(1): 84-94. http://dx.doi.org/10.1080/0305569980240106 
Moulin, D. 2011. “Giving voice to 'the silent minority': The experience of religious students in secondary school religious education lessons." British Journal of Religious Education 33(3): 313-326. http://dx.doi.org/10.1080/01416200.2011.595916

Pike, M. 2010." Transaction and transformation at Trinity: private sponsorship, core values and Christian ethos at England's most improved academy." Oxford Review of Education 36(6): 749-765. http://dx.doi.org/10.1080/03054985.2010.510625

Rothgangel, M. 2014. Religionspädagogik im Dialog I: Disziplinäre und interdisziplinäre Grenzgänge. [Religious education pedagogy in dialogue 1: disciplinary and interdisciplinary border crossings] Vienna: Kohlhammer.

Russo, C. (ed.) 2012. Religion in Schools. Thousand Oaks: Sage.

Stern, J. 2010. "Research as pedagogy: building learning communities and religious understanding in RE." British Journal of Religious Education 32(2): 133-146.

http://dx.doi.org/10.1080/01416200903537415

ter Avest, I., D.-P. Jozsa, T. Knauth, J. Rosón, and G. Skeie. 2009. Dialogue and Conflict on Religion. Studies of Classroom Interaction in European Countries. Münster: Waxmann

Valk P., G. Bertram-Troost, M. Friederici, C. Béraud (eds.) 2009. Teenagers' Perspectives on the Role of Religion in their Lives, Schools and Societies: A European Quantitative Study. Münster: Waxmann 
Walford, G. 2006. Private education: tradition and diversity. London: Continuum.

Walford, G. 2008. "Faith-based schools in England after ten years of Tony Blair." Oxford Review of Education 34(4): 689-99. http://dx.doi.org/10.1080/03054980802518896

White, J. and M. Peters (eds.). 2011. Bakhtinian pedagogy. Peter Lang: New York.

Wright, A. 2007. Critical Religious Education, Multiculturalism and the Pursuit of Truth. Cardiff: University of Wales Press.

Wright, A. 2012. "Fantasies of empowerment: mapping neoliberal discourse in the coalition government's schools policy." Journal of Education Policy 27(3): 279-294.

http://dx.doi.org/10.1080/02680939.2011.607516

Zucca, L. 2013. A secular Europe: law and religion in the European constitutional landscape. Oxford: Oxford University Press. 